\title{
LIETUVOS GYVENTOJŲ PAJAMŲ IR VARTOJIMO DIFERENCIACIJA
}

\author{
Vaida Lisauskaitè \\ M. Romerio universitetas, Ateities g. 20, LT-08303 Vilnius, Lietuva \\ El.paštasvaida@mruni.eu
}

Iteikta 2010-03-01; priimta 2010-05-20

\begin{abstract}
Santrauka. Straipsnyje aptariami pastarųjų metų Lietuvos gyventojų gyvenimo lygio skirtumai, analizuojant pajamų ir vartojimo išlaidų pokyčius, struktūrą ir diferenciaciją. Straipsnyje teigiama, kad bendras šalies ekonominis augimas, vertinamas pagal tokius rodiklius, kaip BVP augimas, BVP, tenkantis vienam gyventojui, dar neužtikrina gyventojų gerovès, gyvenimo kokybės, pasitenkinimo gyvenimu didèjimo. Vertinant gyventojų gerovès pokyčius tikslingiau nagrinèti pajamų ir vartojimo išlaidų pasiskirstymą tarp atskirų visuomenės grupių. Tokia statistinių duomenų analizė atskleidžia vis gilejjančią Lietuvos gyventojų turtinę nelygybę.
\end{abstract}

Reikšminiai žodžiai: ekonomikos augimas, gyventojų pajamų lygis ir diferenciacija, vartojimo išlaidų diferenciacija, poliarizacija, nelygybė, socialiniai skirtumai, gyvenimo kokybè.

\section{DIFFERENTIATION OF INCOME AND CONSUMPTION OF THE LITHUANIAN POPULATION}

\author{
Vaida Lisauskaitė \\ M. Romeris University, Ateities g. 20, LT-08303 Vilnius, Lithuania \\ E-mail:vaida@mruni.eu
}

Received 1 March 2010; accepted 20 May 2010

\begin{abstract}
The article discusses the current disparities as regards the standard of living of the Lithuanian population by analysing changes in the structure and differentiation of income and consumption expenditure. This article claims that the overall economic growth of the country evaluated according to such indicators as the growth of GDP and GDP per capita, is still unable to ensure the welfare, quality of life and increase of life satisfaction among the population. With regard to evaluation of the changes in the welfare of the population, it is appropriate to consider distribution of income and consumption expenditure among different groups of society. Such an analysis of statistical data reveals the growing wealth inequality among the Lithuanian population.
\end{abstract}

Keywords: economic growth, level and differentiation of income of the population, differentiation of consumption expenditure, polarisation, inequality, social disparities, quality of life. 


\section{Ivadas}

Pasaulyje vis labiau plinta nuomoné, kad ekonominius pasiekimus iliustruojantys rodikliai - BVP augimas, BVP, tenkantis vienam gyventojui, ir kiti santykiniai rodikliai, siejami su gamybiniais veiksniais, prekių ir paslaugų kūri$\mathrm{mu}$, pinigine jų verte, - jau nebeatspindi realios šalies situacijos ir tuo labiau atskiro visuomenés nario pragyvenimo lygio ir gyvenimo gerovés laipsnio.

Prancūzijos prezidento N. Sarkozy iniciatyva 2009 m. sudaryta Ekonomikos būklès ir socialinès plètros įvertinimo komisija (kitaip vadinama Laimès komisija), kuriai vadovauja Kolumbijos universiteto profesorius, Nobelio premijos laureatas Josephas Stiglitzas, rekomendavo vertinant šalies ekonominę ir socialinę pažangą vietoje BVP, į darbo našumą ir pelną orientuotų rodiklių taikyti gyvenimo gerovę perteikiančių rodiklių sistemą. Komisijos parengtame pranešime (Stiglitz et al. 2009) atskleidžiamas ir išryškinamas skirtumas tarp tradicinių ir šiuolaikinių tvarią ekonomikos plètrą apibūdinančių rodiklių. Taikant klasikinę sistemą, anot Laimès komisijos, BVP rodiklio prigimtis yra pernelyg kiekybine, neatsižvelgianti ị gyvenimo kokybès pokyčius. Infliacijos ir biudžeto deficito rodikliams suteikiamas pernelyg didelis svoris, o gyventojų pajamų, vartojimo, ekologinių rodikliu reikšmė sumenkinama. Reikšmingiausia J. Stiglitzo vadovaujamos komisijos išvada ta, kad vertinant ekonominès politikos sẻkmingumą, gamybą atspindintys kiekybiniai rodikliai neparodo tikrosios šalies ekonominès būklès. Jie turi būti pakeisti į visuomenès gerovès ir gyvenimo kokybės rodiklius. Šios komisijos nuomone, pirma, namų ūkių pajamos ir vartojimas yra tinkamesni gyvenimo kokybę atspindintys rodikliai nei BVP vienam gyventojui; antra, itin svarbu tyrinèti ne tik vidutinius pajamų ir vartojimo pokyčius, tačiau ir jų pasiskirstymą tarp turtingiausių bei skurdžiausių socialinių grupių; trečia, šie rodikliai turi būti papildyti darbo ir laisvalaikio santykiu - vienu iš svarbiausių gerovès indikatorių, gyvenamosios aplinkos ir ekologiniais rodikliais.

Ši idejja buvo labai palankiai sutikta iškilių pasaulio ekonomistų - Nobelio premijos laureato Paulo Krugmano, Nourielio Roubini, Klauso Schwabo ir kt., vertinant ją kaip išskirtinę pastarojolaikotarpio idèją. Žinomi Lietuvos ekonomistai (P. Gylys, O. G. Rakauskiené, R. Lazutka, V. Pranulis) taip pat teigia, kad tikrają šalies ekonomikos būklę ir ekonominès politikos efektyvumą parodo ne BVP augimas ir makrofinansiniai rodikliai (Mastrichto kriterijai), o gyventoju gyvenimo gerovès indikatoriai. Jų požiūriu, ekonomikos sèkmè turi būti matuojama per žmogaus prizmę, socialinès ir ekonominès sanglaudos aspektą (Gylys 2008a, 2008b; Lazutka 2007; Rakauskienè2010; Pranulis 2007). Toks požiūris išryškèja ir ES vykdomoje ekonominèje politikoje, kurią visais aspektais persmelkia „socialinè šerdis", t. y. prioritetas teikiamas skurdo, benamystés, socialinès ir finansinès atskirties problemų sprendimui ir jų priežasčiu naikinimui, ypatingas dèmesys ir praktinè parama skiriama pažeidžiamiems visuomenès nariams.
Straipsnio tyrimo objektas - gyventojų pajamų ir vartojimo išlaidų pokyčiai, jų struktūra ir diferenciacija; tikslas - remiantis statistinių duomenų analize ir namų ūkių tyrimų duomenimis, atskleisti Lietuvos gyventojų pajamų ir vartojimo išlaidų nelygybę bei konkrečiose išlaidų grupėse nustatyti diferenciacijos koeficientus kaip rodiklius, atspindinčius visuomenès gerovès ir gyvenimo kokybès lygi.

Tyrimo metodai: rengiant straipsni taikyta mokslinès literatūros sisteminè, lyginamoji ir loginè analizè. Taikyti bendrieji statistikos metodai: duomenų padèties ir sklaidos rodiklių, santykinių dydžiu, duomenų diferenciacijos rodiklių skaičiavimas, pagrindinès vystymosi tendencijos nustatymas. Skaičiavimams naudoti Statistikos departamento prie Lietuvos Respublikos Vyriausybės ir Europos Sajungos statistikos tarnybos (Eurostat) duomenys ir tyrimų rezultatai.

\section{Ekonominis augimas ir socialinè diferenciacija}

BVP rodiklis apibendrina labai sudètingus ekonominius reiškinius, tačiau vienas rodiklis niekada neparodo tikrosios situacijos. Siekiant suvokti ekonominę šalies padèț̨ ir visuomenès gerovès lygi, reikia daug daugiau rodiklių. Pvz., R. Lazutkos teigimu, „ekonomikos augimas gali būti lydimas socialinès diferenciacijos didejimo. Tik gaila, kad mes neturime patikimų rodiklių, kurie atspindètų tą diferenciaciją, kurią šiandien nesunku pastebèti, kaip sakoma, plika akimi. Norèdami būti moksliškai tikslūs, kol kas, deja, galime kalbèti tiktai apie veiksnius, kurie tą diferenciaciją didina" (Lazutka 2005).

Gyvenimo kokybès rodikliai dažnai nepriklauso nuo makroekonomikos rodikliu ir netgi gali su jais negatyviai koreliuoti. Pvz., Pietų Koréjoje 1963-1979 m. labai augant BVP vienam gyventojui, gerejo tik fizinio gyvenimo kokybè, o asmeninio ir socialinio gyvenimo kokybè buvo sustingusi ar netgi smuko (Norkus 2007). Žymi Rusijos mokslininkè, akademikė N. Rimaševskaja teigia, kad, esant vienodam bendram šalies pajamų lygiui, gyvenimo kokybès indikatoriai gali būti labai skirtingi, taigi turi būti atsižvelgiama ir ¡ diferencijuotus rodiklius. Jos siūloma nacionalinè idejja žmogaus branginimas, tautos išsaugojimas ir tausojimas, $\mathrm{o}$ ne finansinio kapitalo kūrimas, nes pagrindinis bet kurios šalies turtas - jos žmogiškasis potencialas (Римашевская 2007). Vadinasi, gyventojų turtejjimas (augantis darbo užmokestis, santaupos ir vartojimas) dar nereiškia gyvenimo kokybès kilimo. Galima sakyti, kad vyksta netgi priešingi procesai: materialine gerove auga kaip tik gyvenimo kokybès sąskaita.

Iprastinè statistika, operuojanti vidutiniais dydžiais, dažnai nepajegi užfiksuoti už šių vidurkių besislepiančio didelio atotrūkio tarp atskirų dydžių kraštutinių verčių. Tai atskleidžia atskirų decilinių ar kvintilinių visuomenès grupių analizès.

Ekonomikos augimo, išreikšto BVP vienam gyventojui, ir Džini koeficiento kaip netolygaus pajamų pasiskirstymo mato, ịtaką visuomenès pasitenkinimui gyvenimu atsklei- 


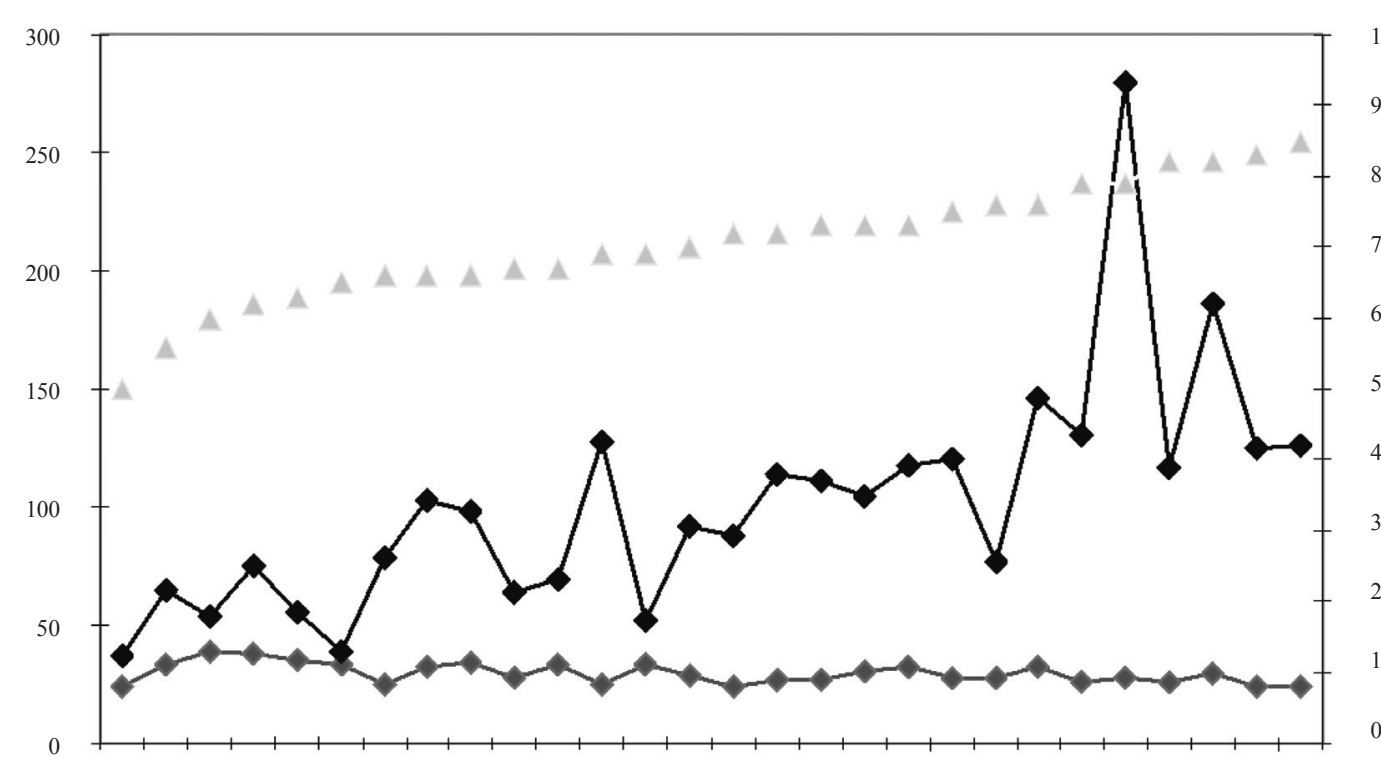

BG HU LV PT LT RO CZ IT EL SK EE AT PL CY SI DE FR ES UK BE MT IE NL LU FI NO SE DK

-Džini koeficientas —BVP, tenkantis 1 gyventojui (pagal PGP) —- Pasitenkinimas gyvenimu

Šaltiniai: Eurostat 2007; European Foundation for the Improvement of Living and Working Conditions 2009.

1 pav. Džini koeficiento, BVP, tenkančio vienam gyventojui, ir gyventojų pasitenkinimo gyvenimu rodikliai Europos šalyse

Fig. 1. Gini coefficient, GDP per capita and life satisfaction indices in European countries

džia objektyvių statistinių duomenų ir subjektyvaus gyventojų apklausos būdu atlikto vertinimo priklausomybès (1 pav.). Šių dydžių kitimo tendencijos rodo, kad ne visada visuomenès gerove priklauso nuo ekonominių šalies pajègumų, išreiškiamų šalyje pagamintų prekių ar suteiktų paslaugų pinigine verte, t. y. šalies gebejjimų sèkmingai vystyti ūkį. Pasitenkinimas gyvenimu beveik tolygiai didèja, mažéjant turtinei diferenciacijai, $\mathrm{t}$. y. Džini koeficiento vertems ${ }^{1}$ svyruojant nuo 24 iki32, pasitenkinimo gyvenimu įvertinimas visose Antrajame Europos gyvenimo kokybės tyrime dalyvavusių šalių visuomenėse viršija 7 balus (pagal dešimtbalę sistemą), o „didesnès nelygybès“šalyse, kuriose Džini koeficiento vertès svyruoja nuo 33 iki39 (tarp ju ir Lietuva su Džini koeficientu 36), pasitenkinimo gyvenimu balas neviršija 6,9 (Second European... 2009).

Subjektyvūs gyventojų gerovès matavimai vartotojiškoje visuomeneje atskleidžia tam tikrus paradoksus - pasitenkinimas gyvenimu nedideja tiesiog proporcingai augančioms paja-

1 Džini (Gini) koeficientas yra pajamų pasiskirstymo nelygybès šalyje rodiklis. Jis apskaičiuojamas kaip ploto tarp Lorenco kreivès ir absoliučiosios lygybès tiesès santykis su bendruoju plotu į apačią nuo absoliučios lygybès tiesès. Naudojant Džini koeficientą nustatomas santykis tarp sukauptos gyventojų, suskirstytų pagal pajamų dydį, dalies ir sukauptos bendros jų gaunamos sumos. Jei būtų tobula lygybė (t. y. kiekvienas asmuo gautų tokias pačias pajamas), šis koeficientas būtų lygus $0 \%$. Jei visos nacionalinès pajamos būtų tik vieno asmens rankose, tada koeficientas būtų $100 \%$. Kuo didesnis koeficientas, tuo didesnè pajamų pasiskirstymo nelygybė šalyje. moms ar $B V P$, tenkančiam vienam gyventojui, t. y. materialinè gerove dar nedaro žmogaus laimingo.

Gyventojų reikmès ir požiūris ị jas daugeliu atvejų dar priklauso ir nuo šalies istorijos, ekonominio išsivystymo, visuomenès mentaliteto, išsilavinimo ir kultūros lygio. Pažymètina, kad pajamų reikšmè individualiai gerovei skiriasi priklausomai nuo asmens šeiminès padèties ar sveikatos būklè-tospačios pajamos ¿vairiems asmenims gali reikšti visiškai skirtinga gerovés lygị.

Minètos priklausomybès taip pat įrodo, kad ekonominis augimas dar negarantuoja socialinés gerovés didejiimo, nes tuo pat metu vyksta nacionalinių pajamų perskirstymas, kuris dèl skirtingo socialinio teisingumo supratimo ir valstybèje vykdomos ekonominès politikos sukelia didesnę ar mažesnę gyventojų pajamų ir vartojimo išlaidų nelygybę. Ypač netolygaus pajamų ir išteklių pasiskirstymo pasekmè - gyventoju poliarizacija, aukšti diferenciacijos rodikliai ir skurdo lygis (Шевяков 2005, 2008). Didejjant nelygybei, skatinančiai žmonių tarpusavio pavydą, stiprèjant konkurencijai ir žmonių santykių komercinimui, naikinančiam tarpusavio pasitikejjimą ir meilę, smunka ir socialinio gyvenimo kokybè.

BVP didejjant net $\sim 10$ proc. per metus, nemažos gyventojų dalies gyvenimo sąlygos taip ir nepagerès, jeigu valstybė nepasirūpins tolygiu ekonominio augimo rezultatų paskirstymu. Dr. R. Lazutkos teigimu, Lietuvai neatsižvelgti į kitų šalių istoriją ir kliautis, kad rinkos jègos viską sutvarkys, kad valstybei nereikia kištis ị rinką, yra labai klaidingas ir ydingas požiūris. 
Ekonomikos vystymasis mūsų šalyje turètu büti parodomas kartu su didëjančia diferenciacija, nes tik vienas BVP augimas neparodo, kokia dalis to produkto tenka vienoms gyventoju grupèms ir kokia - kitoms. Tai reiškia, kad augant ekonomikai vieni labai smarkiai gerina savo padetį, kiti - smarkiai blogina.

Gyventojų pajamų nelygybès didejjimo ignoravimas Lietuvoje gali būti suprantamas pripažinus, kad dažniausiai vadovaujamasi XIX a. pirmoje puseje J. Benthamo suformuluotu teiginiu, jog visuomenès nauda yra paprasta individu naudų suma. Todèl demesys kreipiamas tik ị BVP augimą, bet ne i jo paskirstymą. Per 150 metų buvo padaryta bent keletas reikšmingų atradimų aiškinant socialinę gerovę. Visi jie vienaip ar kitaip visuomenés gerovę sieja ne tik su individu turimų išteklių (gaunamu pajamu) dydžiu, bet ir su ju pasiskirstymu arba nelygybe (Lazutka 2003: 22-29).

Lietuvos ekonominė politika išsiskiria iš ES šalių beatodairišku tikejjimu laisvąa rinka ir visišku socialinio teisingumo nepaisymu. Valstybė turi stebėti nelygybès kitimą, analizuoti ne tik vidutinius pajamų ir vartojimo pokyčius, bet ir jų pasiskirstymą tarp turtingiausių ir skurdžiausių visuomenès grupių, nes didejantys turtiniai netolygumai ir socialiniai skirtumai ilgainiui ima kenkti ekonominiam šalies vystymuisi.

\section{Lietuvos gyventojų pajamų pokyčiai, jų struktūra ir diferenciacija}

Iki 2008 m. pabaigos nuolat didejjant užimtumui (užimtumo lygis Lietuvoje nuosekliai didejo - nuo 57,5 proc. $2001 \mathrm{~m}$. iki 65,0 proc. 2008 m.) ir mažèjant nedarbui (žemiausias nedarbo lygis atkūrus nepriklausomybę buvo užfiksuotas 2007 m. - 4,3 proc.) sparčiai augo ir darbo užmokestis pagrindinis gyventojų pajamų šaltinis. Vidutinis mènesinis darbo užmokestis 2000-2008 m. išaugo beveik tris kartus ir 2008 m. siekė 2174 Lt. Ypač aukšti darbo užmokesčio didejjimo tempai užfiksuoti įstojus į ES ir siekè 17-20 proc. per metus.

Kaip rodo Lietuvos gyventojų pajamų pokyčiai, atkūrus nepriklausomybę pajamos nuosekliai augo ir disponuojamosios pajamos vienam asmeniui 2000-2008 m. padidejo daugiau kaip du kartus - iki 987 Lt per ménesį. Didžiausi pajamų augimo tempai buvo 2007 m. - palyginti su praejusiais metais, gyventoju disponuojamosios pajamos padidejo net 26,2 proc. (1 lentelè).

Tačiau gyventojų pajamų struktūra pagal šaltinius rodo neigiamą darbo rinkos ir demografinę situaciją šalyje: situacija darbo rinkoje suformavo platų sluoksnį žmonių, gyvenančių iš socialinių pašalpų ( 5 proc. gyventojų, iš kurių didesnè dalis - kaime), beveik trečdalio namų ūkių $(27,2$ proc.) pagrindinis pajamų šaltinis - senatvės pensijos (kaime šis procentas - net 36,2 proc.), kurios vis dar labai atsilieka nuo vidutinio ES pensijų lygio, net 7 proc. vieno suaugusio asmens su vaikais namų ūkių gyvena iš pajamų, reguliariai gaunamų iš kitų ūkių - dažniausiai alimentų.

Netolygų pajamų pasiskirstymą atskleidžia ir vidutinių pajamų, tenkančių vienam namų ūkio nariui, ir Džini koefici-

1 lentelè. Gyventojų darbo užmokestis ir pajamos (remiantis Statistikos departamento duomenimis)

Table 1. Wages and income of population (according to the data of Statistics Lithuania)

\begin{tabular}{|c|c|c|c|c|c|c|}
\hline Metai & $\begin{array}{c}\text { Vidutinis } \\
\text { mėnesinis } \\
\text { darbo užmo- } \\
\text { kestis, Lt }\end{array}$ & $\begin{array}{c}\text { Vidutinio } \\
\text { mėnesinio darbo } \\
\text { užmokesčio } \\
\text { pokytis, proc. }\end{array}$ & $\begin{array}{c}\text { Pajamos (vienam } \\
\text { namų ūkio nariui } \\
\text { vidutiniškai } \\
\text { per mėn.), } \mathbf{L t}\end{array}$ & $\begin{array}{c}\text { Pajamų } \\
\text { vienam namų } \\
\text { ūkio nariui } \\
\text { pokytis, proc. }\end{array}$ & $\begin{array}{c}\text { Nedarbo } \\
\text { lygis, proc. }\end{array}$ & $\begin{array}{c}\text { Užimtumas, } \\
\text { proc. }\end{array}$ \\
\hline 2000 & 980,8 & 0,5 & 415,4 & - & 11,5 & 54,3 \\
\hline 2001 & 982,3 & 1,2 & 409,9 & $-1,3$ & 13,0 & 57,5 \\
\hline 2002 & 1013,9 & 3,2 & 422,0 & 3,0 & 14,7 & 59,9 \\
\hline 2003 & 1072,6 & 5,8 & 457,6 & 8,4 & 12,9 & 61,1 \\
\hline 2004 & 1149,3 & 7,2 & 495,8 & 8,3 & 12,2 & 61,2 \\
\hline 2005 & 1276,2 & 11,0 & 579,7 & 16,9 & 11,8 & 62,6 \\
\hline 2006 & 1495,7 & 17,2 & 680,8 & 17,4 & 8,3 & 63,6 \\
\hline 2007 & 1802,4 & 20,5 & 859,3 & 26,2 & 5,4 & 64,9 \\
\hline 2008 & 2174,1 & 17,1 & 987,0 & 14,9 & 5,8 & 65,0 \\
\hline $2009 *$ & 2052,0 & $-5,6$ & 927,5 & $-6,0$ & 13,8 & 60,4 \\
\hline $2010 * *$ & 1892,0 & $-7,8$ & 875,5 & $-5,6$ & 16,7 & 58,8 \\
\hline
\end{tabular}

* Negalutiniai duomenys.

** Finansu ministerijos skelbiamos Lietuvos ekonominiu rodikliu projekcijos (2010-02-01) ir autoriaus prognozés. 


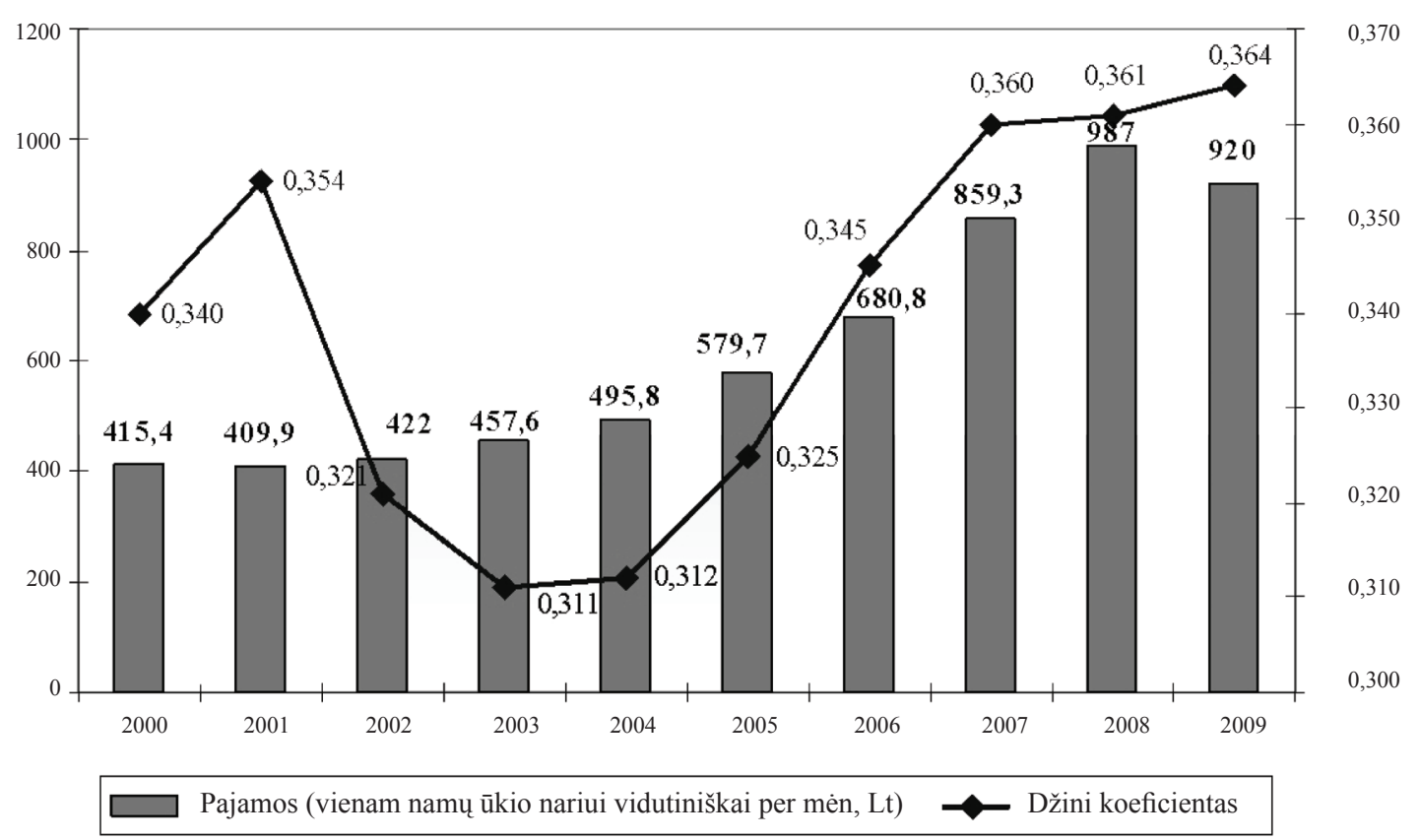

2 pav. Vidutinių pajamų ir Džini koeficiento kitimo tendencijos 2000-2009 m.

Fig. 2. Variation trends of average income and Gini coefficient in 2000-2009 m.

entų tarpusavio ryšys (2 pav.), kuris rodo, kad didejant bendrai gyventoju gaunamu pajamų sumai tuo pačiu metu dideja atotrūkis tarp daugiausiai ir mažiausiai pajamu gaunančiu visuomenés grupių. Gilejanti pajamų diferenciacija visuomenèjekelia socialinę ittampą, nes, kylant bendram gyvenimo lygiui, atskirų visuomenès grupių padètis negerèja, mat skurdesnių visuomenès grupių pajamų augimas atsilieka nuo turtingesnio sluoksnio pajamų augimo (Šileika, Blažienė 2000a, 2000b) (2 lentelè).

Neigiamą ekonominio augimo ir gyventojų pragyvenimo lygio, vertinamo pagal pajamų pasiskirstymo tolygu-

2 lentelè. Disponuojamų pajamų augimas deciliuose 2006 m. (remiantis Statistikos departamento duomenimis)

Table 2. Growth of disposable income by deciles in 2006 (according to the data of Statistics Lithuania)

\begin{tabular}{c|c|c|c|c|c|c|c|c|c|c}
\hline Deciliai & I & II & III & IV & V & VI & VII & VIII & IX & X \\
\hline Augimas, proc. & 10,98 & 10,69 & 10,97 & 11,10 & 10,79 & 10,67 & 11,04 & 11,17 & 11,96 & 17,11 \\
\hline
\end{tabular}

3 lentelè. BVP ir pajamų diferenciacijos pokyčiai 1996-2008 m. (remiantis Statistikos departamento duomenimis)

Table 3. Variation of GDP and income differentiation in 1996-2008 (according to the data of Statistics Lithuania)

\begin{tabular}{l|c|c|c|c|c|c|c|c|c|c|c|c|c}
\hline \multicolumn{1}{c|}{ Metai } & $\mathbf{1 9 9 6}$ & $\mathbf{1 9 9 7}$ & $\mathbf{1 9 9 8}$ & $\mathbf{1 9 9 9}$ & $\mathbf{2 0 0 0}$ & $\mathbf{2 0 0 1}$ & $\mathbf{2 0 0 2}$ & $\mathbf{2 0 0 3}$ & $\mathbf{2 0 0 4}$ & $\mathbf{2 0 0 5}$ & $\mathbf{2 0 0 6}$ & $\mathbf{2 0 0 7}$ & $\mathbf{2 0 0 8}$ \\
\hline $\begin{array}{l}\text { Realaus } \\
\text { BVP augimo } \\
\text { tempai }\end{array}$ & 5,1 & 8,5 & 7,5 & $-1,5$ & 3,3 & 6,7 & 6,9 & 10,2 & 7,4 & 7,8 & 7,8 & 9,8 & 2,8 \\
\hline $\begin{array}{l}\text { Pajamuc } \\
\text { kraštutinių } \\
\text { decilių } \\
\begin{array}{l}\text { X ir I) } \\
\text { santykis }\end{array}\end{array}$ & 12,7 & 10,45 & 11,23 & 11,58 & 13,26 & 13,34 & - & - & - & 9,32 & 9,48 & 9,87 & - \\
\hline $\begin{array}{l}\text { Džini } \\
\text { koeficientas }\end{array}$ & 0,336 & 0,316 & 0,322 & 0,321 & 0,340 & 0,354 & 0,321 & 0,311 & 0,312 & 0,325 & 0,345 & 0,360 & 0,361 \\
\hline
\end{tabular}




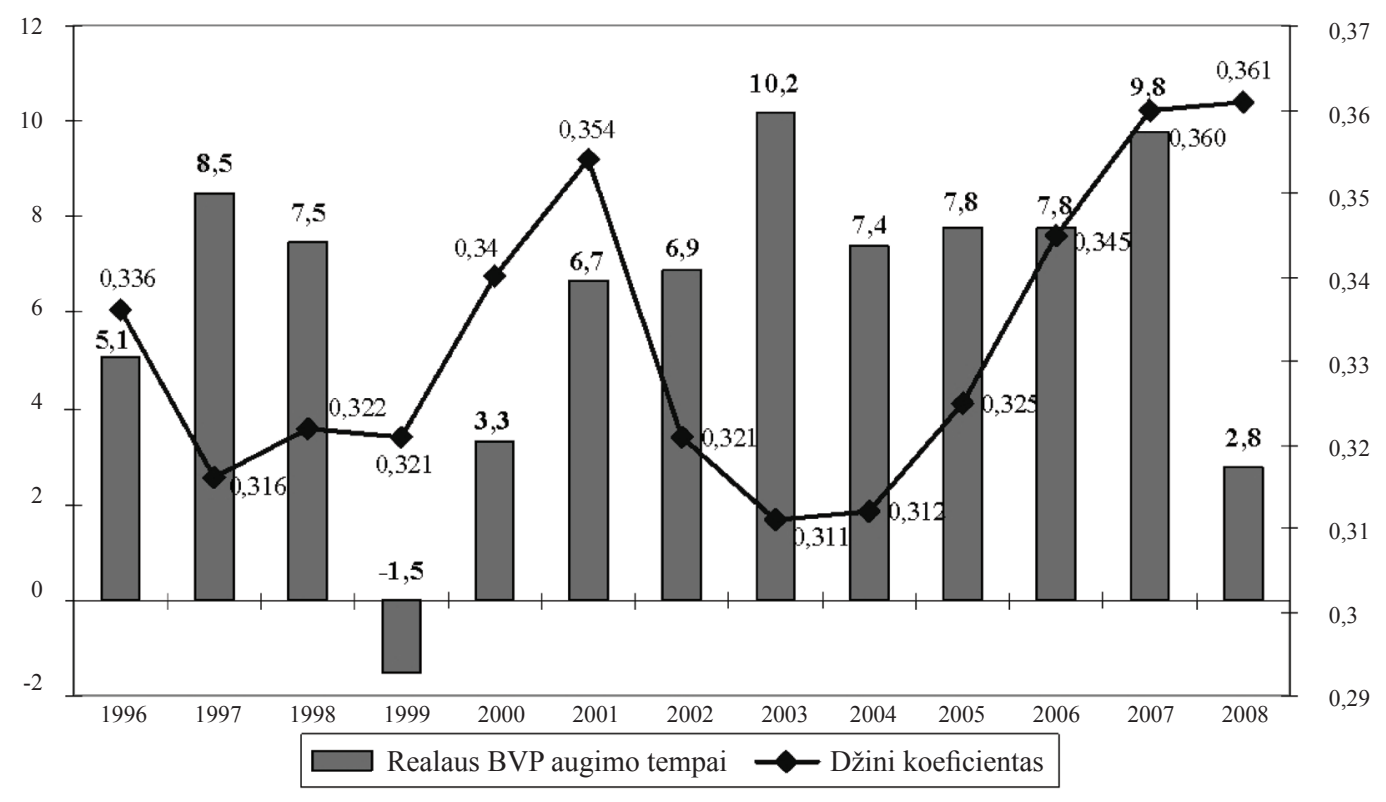

3 pav. BVP ir Džini koeficiento kitimo tendencijos 1996-2008 m.

Fig. 3. Variation trends of GDP and Gini coefficient in 1996-2008

4 lentelè. Lietuvos gyventojų disponuojamų pajamų decilių santykiai 2006 m. (remiantis Statistikos departamento duomenimis)

Table 4. Deciles proportion of disposable income of Lithuanian population in 2007 (according to the data of Statistics Lithuania)

\begin{tabular}{l|l|l|l|l|l}
\hline Deciliai & $\mathbf{X} / \mathbf{I}$ & IX/II & VIII/III & VII/IV & VI/V \\
\hline Santykis & 9,48 & 3,60 & 2,26 & 1,58 & 1,16 \\
\hline
\end{tabular}

mą, koreliaciją atskleidžia ir Lietuvos BVP, disponuojamų pajamų kraštutinių decilių santykio ir Džini koeficiento tarpusavio ryšys (3 lentelè, 3 pav.). Remiantis statistiniais duomenimis, 2003-2007 m. ypač augant šalies BVP, gyventojų pajamų nelygybė didejjo, o tai reiškia galimą netolygų nacionalinių pajamų perskirstymą tarp atskirų socialinių grupių, tarp darbdavių ir samdomųjų, tarp viešojo ir privačiojo sektorių, tarp atskirų ùkio šakų.

Pajamų nelygybė, nors ir po truputį mažejjanti, Lietuvoje yra viena didžiausių tarp ES valstybių narių. Penktadalio didžiausias pajamas gaunančiu Lietuvos gyventojų pajamos $2006 \mathrm{~m}$. buvo 6,3 karto didesnès už penktadalio mažiausias pajamas gaunančių asmenų, o kraštutinių decilių pajamos skiriasi net 9,5 karto (4, 5 lentelès). ES-25 pajamų nelygybès tarp kraštutinių kvintilių vidurkis $2006 \mathrm{~m}$. buvo 4,8 karto. Austrijoje ir Liuksemburge fiksuojamas žemiausias nelygybès skirtumas - nuo 3,3 iki 3,8, o didžiausia nelygybè - Lenkijoje, Latvijoje, Lietuvoje ir Portugalijoje: nuo 6,5 iki 8,2.
5 lentelè. I ir V kvintilinių grupių pajamų skirtumai

Table 5. Income differences by I and V quintile groups

\begin{tabular}{l|c|c|c|c|c}
\hline $\begin{array}{l}\text { S80/S20 } \\
\text { kvintiliu } \\
\text { santykis }\end{array}$ & $\mathbf{1 9 9 7}$ & $\mathbf{2 0 0 1}$ & $\mathbf{2 0 0 6}$ & $\mathbf{2 0 0 8}$ & $\mathbf{2 0 1 0}$ \\
\hline Lietuva & 5,5 & 6,5 & 6,3 & 5,9 & $6,2^{*}$ \\
\hline ES-15 & 4,8 & 4,5 & 4,8 & - & - \\
\hline
\end{tabular}

* Autorès prognozès.

Lietuvos gyventojų pajamų pasiskirstymas kvintilinėse grupèse ( 6 lentelè) leidžia ịvertinti ne tik pajamų diferenciacijos rodiklius tarp kraštutinių kvintilinių grupių, bet ir atskleidžia faktą, kad 41 proc. visų disponuojamų pajamu tenka 20 proc. Lietuvos gyventojų, beveik du trečdalius visų gyventojų pajamų gauna 40 proc. gyventojų. I kvintilio visuomenès grupe disponuoja tik 7 proc. visų pajamų.

\section{Vartotojų visuomenės susiformavimas Lietuvoje}

Z. Baumano teigimu, daugumai šiuolaikinès visuomenès narių individuali laisvè reiškia vartotojo laisvę su visais jos priimtinais ir ne visai priimtinais atributais (Bauman 1988). Lietuvai persiorientuojant iš komandinès tarybinių laikų ekonomikos, kuri buvo pajègi užtikrinti tik pagrindinius poreikius, buvo išlaisvinta „svajonë“ apie laisvą vartojimą, pirkimas tapo galimybe pademonstruoti savo perkamają galią. Z. Baumano teigimu, vienas pagrindinių skirtumų tarp 
6 lentelè. Pajamų lygio ir diferenciacijos rodikliai $2007 \mathrm{~m}$.

Table 6. Income level and differentiation indices in 2007

\begin{tabular}{|c|c|c|c|c|c|c|}
\hline \multirow{2}{*}{ Pajamų ir išlaidų struktūra } & \multicolumn{5}{|c|}{ Gyventojų kvintilinės grupės pagal pajamų lygi } & \multirow{2}{*}{$\begin{array}{l}\text { Diferenciacijos } \\
\text { koeficientas }(\mathrm{V} / \mathrm{I})\end{array}$} \\
\hline & I & II & III & IV & $\mathrm{V}$ & \\
\hline $\begin{array}{l}\text { Ekvivalentinès piniginès disponuojamos pajamos } \\
\text { vienam sąlyginiam asmeniui per mén., Lt }\end{array}$ & 395,1 & 700,9 & 949,5 & 1288,7 & 2329,2 & 5,9 \\
\hline $\begin{array}{l}\text { Pajamų dalis nuo visų piniginių disponuojamų } \\
\text { pajamų, tenkanti kvintilinei grupei, proc. }\end{array}$ & 7 & 12 & 17 & 23 & 41 & 5,9 \\
\hline
\end{tabular}

komunistinio režimo ir Vakarų vartotojiško kapitalizmo buvo galimybės apsipirkti (shopping) stoka. Išlaisvinus visuomenę nuo sunkumų issigyti deficitines ir itin vertinamas vakarietiškas prekes, vis labiau èmè plisti vartotojiška ideologija, orientacija ị materialinę naudą, finansinę sèkmę, pelno siekimą. Vis labiau didèjant primetamos ,amerikietiškosios kultūros“, griaunančios šeimini gyvenimą ir vietines tradicijas, ịtakai, tapo tarsi natūralu siekti asmeninès naudos, būti pragmatiškais vartotojais, o ne asmenybemis, orientuotomis i profesini augimą, dvasinị asmenybès tobulejimą.

Gyventojų materialinès būklès raidos tendencijos Lietuvoje pastaraisiais metais rodè pastebimą gyventojų gyvenimolygio augimą. Šiame kontekste ịspūdingai augo vartojimo mastas: $2000 \mathrm{~m}$. namų ūkių vartojimo išlaidos sudare 64 proc. BVP, o 2008 m. - jau beveik 67 proc.; vidutinès vartojimo išlaidos vienam šeimos nariui 2008 m., palyginti su 2000 m., padidèjo beveik du kartus. Individualių automobilių skaičius per visą rinkos ekonomikos laikotarpị nuosekliai augo ir $2008 \mathrm{~m}$. buvo registruota 1,6 mln. individualių lengvụjų automobilių, t. y. tūkstančiui gyventojų teko 490 lengvụjų automobilių, arba vidutiniškai vienas automobilis dviem gyventojams. Ypač augo apsirūpinimas informacijos ir ryšiu priemonemis: 2009 m. asmeninius kompiuterius namuose turèjo 52,2 proc., mobiliuosius telefonus - net 85,1 proc. namų ùkių.

Tačiau vartojimo išlaidų rezultatus drastiškai pakoregavo ekonominis sunkmetis - $2008 \mathrm{~m}$. namų ūkio vartojimo išlaidos krito net 16,7 proc., ir jų kilimas dar nenumatomas per artimiausius dvejus metus (4 pav.)

Kai šalyje vykdoma griežta fiskalinè politika, t. y. prioritetas teikiamas biudžeto deficito mažinimui, apkarpant išlaidas, ekonomikos teorijoje pasireiškia gerai žinomas taupymo paradoksas - nuolatinis valstybès išlaidų mažinimas leidžia subalansuoti biudžetą tam tikru einamuoju laikotarpiu, tačiau ilgesniu periodu ši priemonè ima neigiamai veikti visą biudžeto formavimą: taupant, t. y. mažinant valstybès išlaidas, ilgainiui ima mažèti ir valstybès pajamos. Besaikis taupymas yra nuosmukįlemiantis veiksnys: reikia skatinti ekonomikos augimą, o ne perdètai taupyti (Rakauskiené, Makauskaitè 2004: 33-42).

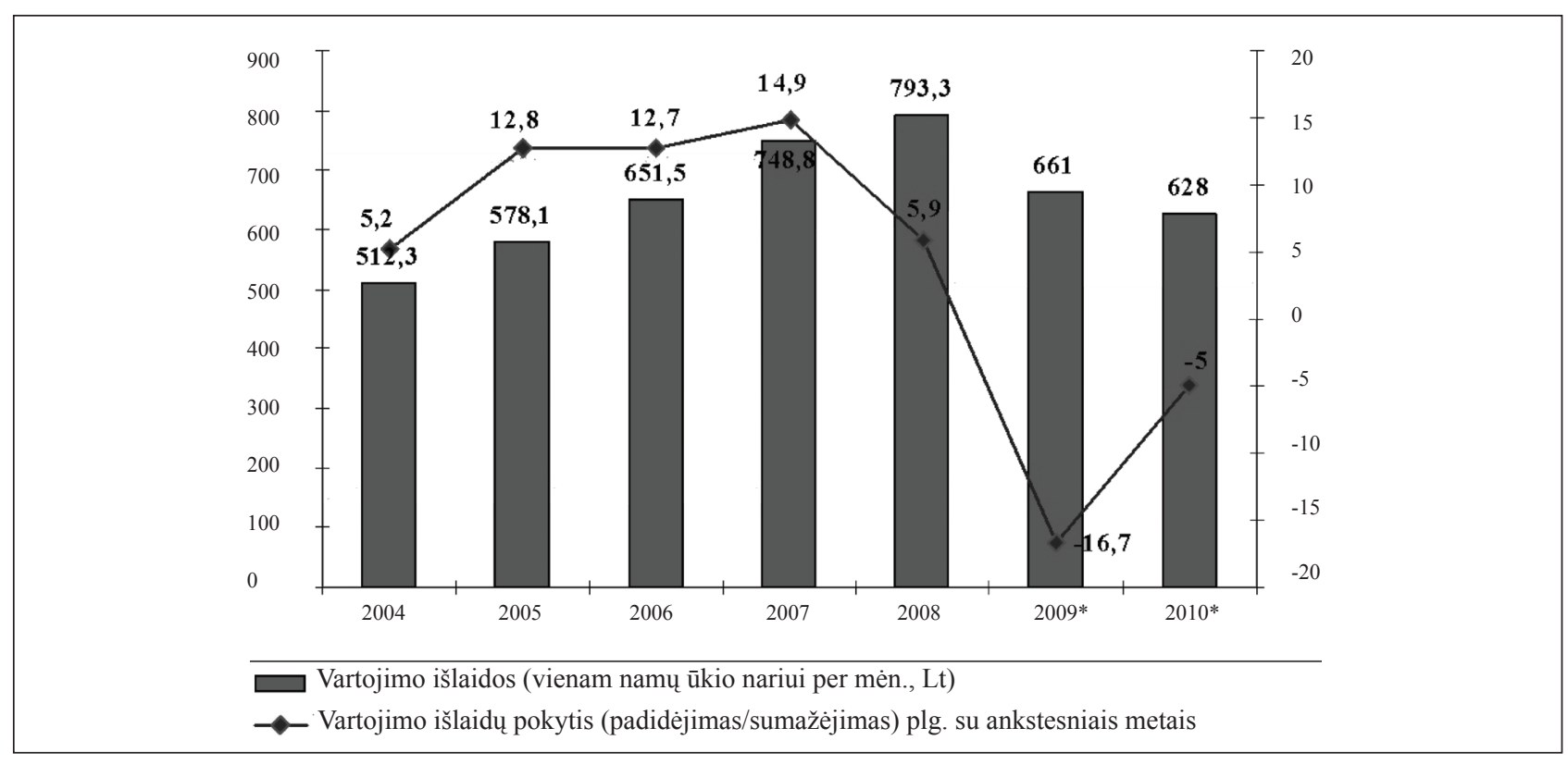

* Prognozès pagal Finansų ministerijos Lietuvos ekonominių rodiklių projekcijas, 2010-02-01.

4 pav. Bendra vartojimo išlaidų dinamika Lietuvoje 2004-2010 m.

Fig. 4. Total dynamics of consumption expenditure in Lithuania in 2004-2010 


\section{Vartojimo išlaidų struktūra}

Gyventoju gyvenimo lygị aiškiai parodo vartojimo išlaidụ pasiskirstymas ir vienas iš svarbiausių rodiklių šioje srityje - išlaidos, skiriamos maistui. Pagal šį rodikli galima spręsti apie šalies gyvenimo lygi - kuo mažesné išlaidų maistui lyginamoji dalis, tuo aukštesnis šalies gyventoju gyvenimo lygis. Vartojimo srityje Lietuvoje pastebimas akivaizdus proveržis - rinkos reformų pradžioje 1996 m. išlaidos maistui sudarè net 55 proc., o $2007 \mathrm{~m}$. - 33 proc., t. y. 1,7 karto mažiau. Rinkos laikotarpiu ryški tendencija išlaidų maistui lyginamojo svorio mažejjimas (7 lentelè).

Tačiau didelio plètros masto šalyse, pvz., JAV, ES šalyse senbuvese, ši išlaidų maistui dalis sudaro 15-20 proc. Taigi daugiau kaip trečdalis išlaidų, skiriamų maistui (2008 m. net 35 proc.) Lietuvoje liudija apie gana žemą gyvenimo lygi. Tai patvirtina ir kiti vartojimo išlaidų rodikliai.

Iki 2008 m. krizès teigiamai reikètų vertinti išlaidų didejjimą poilsiui ir kultūrai, drabužiams ir avalynei, būsto apstatymui, transportui ir komunikacijoms. Tačiau tenka pabrežti, kad antimonopolinès politikos nebuvimas Lietuvoje ir augančios kainos už komunalines paslaugas turi bene didžiausią reikšmę gyventojų pragyvenimo lygiui: nemaža dalis (apie 13 proc.) vartojimo išlaidụ tenka mokesčiams už būsto nuomą, elektrą, dujas, šildymą, vandeni, komunalines paslaugas, todèl galima pagrịstai teigti, kad maždaug pusę Lietuvos gyventojų vartojimo išlaidų sudaro išlaidos būtiniausioms reikmèms, t. y. vien tik maistui ir būstui išlaikyti.

Lyginant Lietuvos ir ES šalių vartojimo išlaidų struktūrą (ES-27 šalių vidurkị kiekvienoje išlaidų grupeje), matomas akivaizdus skirtumas tarp išlaidų, skiriamų maistui - ES šalyse šioms reikmėms vidutiniškai išleidžiama net tris kartus mažiau (remiantis $2005 \mathrm{~m}$. statistiniais duomenimis, tačiau situacija praktiškai nepasikeitè ir 2008 m., 8 lentelè). Nors būstui išlaikyti ES šalyse skiriama daugiau lèšų, tačiau bendra išlaidų maistui ir būstui suma sudaro apie trečdalį visų pajamų ir neviršija Lietuvos gyventojų išlaidų, skiriamų vien tik maisto produktams. Gerokai skiriasi ir išlaidų poilsiui bei kultūrai rodikliai. Lietuvos gyventojai šiems poreikiams patenkinti skiria mažiau kaip 5 proc. visų savo išlaidų, o tai beveik du kartus mažiau nei vidutiniškai ES šalyse (Celik, Ozerkek 2009).

7 lentelè. Namų ūkių vartojimo išlaidų struktūra (remiantis Statistikos departamento duomenimis, proc.)

Table 7. Consumption expenditure structure of households (according to the data of Statistics Lithuania, in per cent)

\begin{tabular}{|c|c|c|c|c|c|c|c|c|c|c|c|}
\hline & 2000 & 2001 & 2002 & 2003 & 2004 & 2005 & 2006 & 2007 & 2008 & $2009^{*}$ & $2010^{\star *}$ \\
\hline Vartojimo išlaidos & 100 & 100 & 100 & 100 & 100 & 100 & 100 & 100 & 100 & 100 & 100 \\
\hline Maisto produktai & 44,4 & 42,4 & 38,4 & 39,5 & 38,8 & 36,6 & 33,7 & 33,1 & 34,8 & 39,7 & 41,2 \\
\hline Alkoholiniai gèrimai & 2,3 & 2,2 & 2,0 & 2,3 & 2,3 & 2,4 & 2,5 & 2,5 & 2,6 & 2,8 & 2,6 \\
\hline Tabako gaminiai & 1,6 & 1,5 & 1,6 & 1,5 & 1,5 & 1,4 & 1,2 & 1,2 & 1,3 & 1,4 & 1,3 \\
\hline Drabužiai ir avalynè & 6,8 & 6,5 & 7,9 & 7,9 & 8,2 & 8,6 & 8,8 & 9,2 & 8,5 & 7,2 & 7,0 \\
\hline $\begin{array}{l}\text { Būstas, vanduo, } \\
\text { elektra, dujos, kitas } \\
\text { kuras }\end{array}$ & 13,5 & 13,6 & 13,2 & 12,7 & 12,2 & 12,0 & 12,0 & 12,0 & 12,6 & 13,7 & 15,2 \\
\hline Būsto apstatymas & 4,2 & 5,1 & 5,3 & 3,8 & 4,2 & 4,5 & 5,5 & 5,8 & 5,0 & 4,2 & 3,9 \\
\hline Sveikatos priežiūra & 4,4 & 4,5 & 5,3 & 4,9 & 5,2 & 5,1 & 5,0 & 4,8 & 4,9 & 4,6 & 4,5 \\
\hline Transportas & 7,6 & 7,3 & 7,1 & 8,6 & 8,8 & 8,8 & 10,3 & 10,4 & 9,8 & 9,5 & 9,1 \\
\hline Ryšiai & 3,6 & 4,5 & 5,0 & 5,2 & 5,0 & 5,0 & 5,0 & 4,9 & 4,6 & 4,0 & 3,7 \\
\hline Poilsis ir kultūra & 3,8 & 4,0 & 4,9 & 4,3 & 4,4 & 4,7 & 5,2 & 5,5 & 4,8 & 3,9 & 3,4 \\
\hline Švietimas & 0,6 & 0,7 & 0,6 & 0,8 & 0,9 & 1,2 & 0,9 & 0,8 & 0,6 & 0,7 & 0,6 \\
\hline $\begin{array}{c}\text { Viešbučiai, kavinès, } \\
\text { restoranai }\end{array}$ & 4,2 & 4,2 & 4,3 & 4,2 & 4,1 & 5,0 & 4,8 & 5,2 & 5,5 & 4,6 & 4,2 \\
\hline $\begin{array}{l}\text { Ivairios prekès ir } \\
\text { paslaugos }\end{array}$ & 3,0 & 3,5 & 4,4 & 4,3 & 4,4 & 4,6 & 4,9 & 4,7 & 5,0 & 3,7 & 3,3 \\
\hline
\end{tabular}

* Negalutiniai duomenys.

${ }^{\star *}$ Autoriaus prognozès. 
8 lentelè. Namų ūkių vartojimo išlaidų struktūra ES-27, 2005 ir 2008 m. (remiantis Eurostat ir Statistikos departamento duomenimis, proc. nuo visų vartojimo išlaidų)

Table 8. Consumption expenditure structure of households in EU-27, in 2005 and 2008 (according to the data of Eurostat and Statistics Lithuania, per cent of total consumption expenditure)

\begin{tabular}{|c|c|c|c|}
\hline Vartojimo išlaidos & EU-27, 2005 & Lt, 2005 & Lt, 2008 \\
\hline Maisto produktai ir nealkoholiniai gèrimai & 12,8 & 36,6 & 34,8 \\
\hline Alkoholiniai gèrimai, tabako gaminiai, narkotinės medžiagos & 3,6 & 3,8 & 3,9 \\
\hline Drabužiai ir avalynè & 5,8 & 8,6 & 8,5 \\
\hline Būstas, vanduo, elektra, dujos, kitas kuras & 21,7 & 12,0 & 12,6 \\
\hline Būsto apstatymas, namų apyvokos įranga ir kasdienè būsto priežiūra & 6,3 & 4,5 & 5,0 \\
\hline Sveikatos priežiūra & 3,5 & 5,1 & 4,9 \\
\hline Transportas & 13,5 & 8,8 & 9,8 \\
\hline Ryšiai & 2,8 & 5,0 & 4,6 \\
\hline Poilsis ir kultūra & 9,5 & 4,7 & 4,8 \\
\hline Švietimas & 1,0 & 1,2 & 0,6 \\
\hline Viešbučiai, kavinès, restoranai & 8,9 & 5,0 & 5,5 \\
\hline İvairios prekès ir paslaugos & 10,7 & 4,6 & 5,0 \\
\hline
\end{tabular}

\section{Vartojimo išlaidų diferenciacija}

Remiantis Eurostat rekomendacijomis, vertinant gyventojų gerovę tikslinga analizuoti ne tik bendrą vartojimo išlaidų pasiskirstymą tarp atskirų išlaidų grupių, bet ir jų pasiskirstymą atskirose visuomenès grupèse (deciliuose) (Living conditions... 2006, 2007, 2008, 2009).
Duomenys apie pajamų nelygybę ir netolygų vartojimo išlaidų pasiskirstymą yra labai svarbūs vertinant skurdą, nes bendras išteklių pasiskirstymas šalyje lemia ir skurdo lygi. Paprastai šalyse, kuriose yra didelè nelygybè, skurdas yra didesnis (Skurdas ir nelygybė ES 2007).

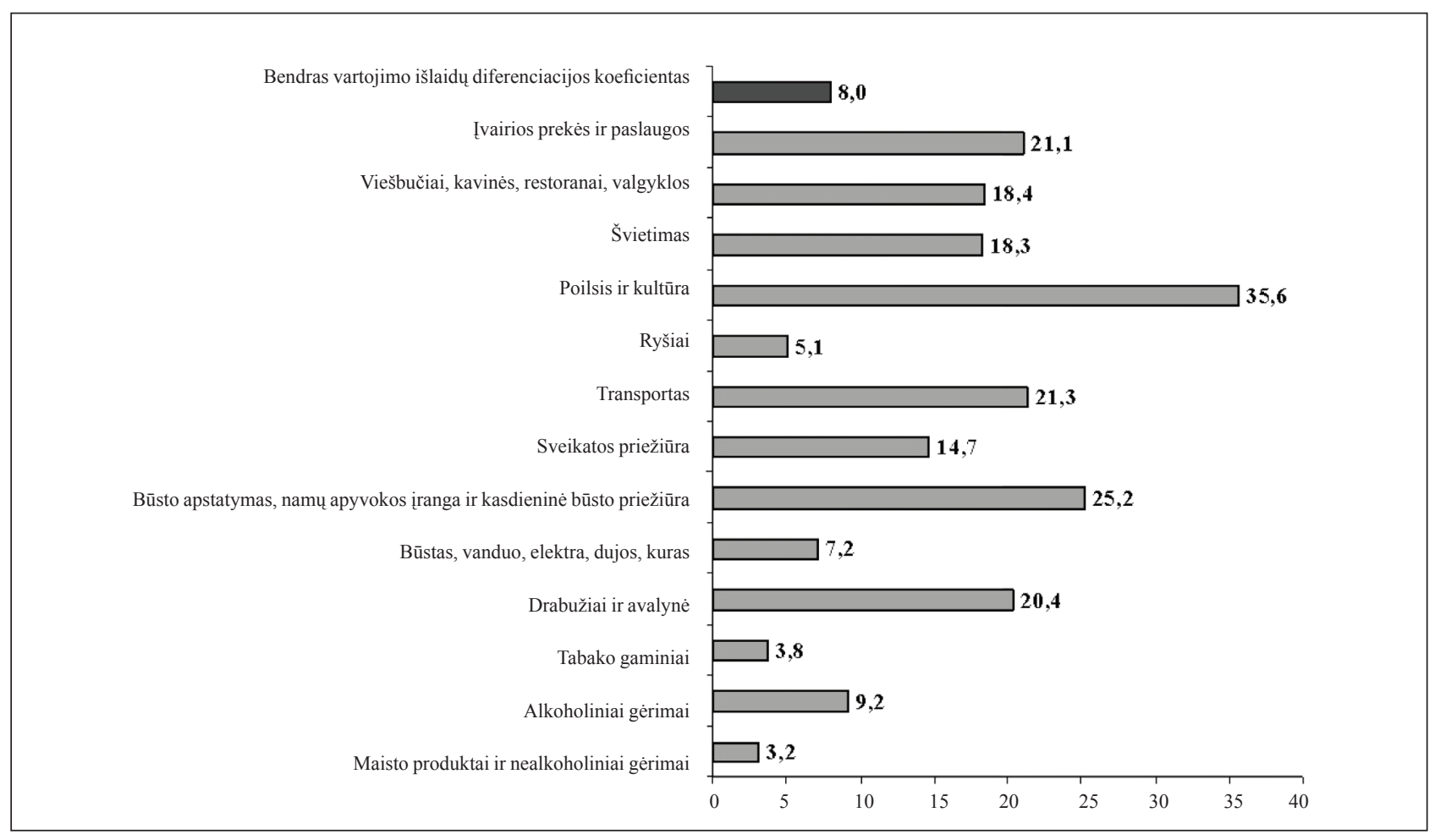

5 pav. Lietuvos gyventojų vartojimo išlaidų diferenciacijos koeficientai $2008 \mathrm{~m}$. (pagal decilių grupes)

Fig 5. Consumption expenditure differentiation indices of Lithuanian population in 2008 (by decile groups) 
Lietuvos gyventojų vartojimo išlaidų dydžiai kraštutiniuose deciliuose pastaruoju metu skiriasi aštuonis kartus (plg. 2007 m. - 9,3 karto) (9 lentelè). Palyginti su 2007 m., šis skirtumas sumažèjo (2007 m. vartojimo išlaidos skyrèsi 9,3 karto, 2006 m. - 8,9 karto). Išlaidos maistui skyrési tris kartus, nors namų ūkiai, vartojimui išleidę mažiausiai, maistui skyrè 55 proc. visų vartojimo išlaidų, o vartojimui išleidę daugiausia - 22 proc. (6, 7 pav.). Ypač dideli skirtumai - poilsio ir kultūros, būsto apstatymo, drabužių ir avalynès įsigijimo srityse (5 pav.).

9 lentelè. Lietuvos gyventojų vartojimo išlaidų diferenciacijos koeficientai (apskaičiuota remiantis Statistikos departamento duomenimis)

Table 9. Consumption expenditure differentiation indices of Lithuanian population (counted according to the data of Statistics Lithuania)

\begin{tabular}{|c|c|c|c|}
\hline Vartojimo išlaidos & $\begin{array}{c}\text { Decilinis } \\
\text { diferenciacijos } \\
\text { koeficientas } \\
(\mathrm{X} / \mathrm{I}) 2006 \mathrm{~m} .\end{array}$ & $\begin{array}{c}\text { Decilinis } \\
\text { diferenciacijos } \\
\text { koeficientas } \\
(\mathrm{X} / \mathrm{I}) 2007 \mathrm{~m} .\end{array}$ & $\begin{array}{c}\text { Decilinis } \\
\text { diferenciacijos } \\
\text { koeficientas } \\
(\mathrm{X} / \mathrm{I}) 2008 \mathrm{~m} .\end{array}$ \\
\hline Iš viso & 8,9 & 9,3 & 8,0 \\
\hline Maisto produktai ir nealkoholiniai gèrimai & 3,0 & 3,2 & 3,2 \\
\hline Alkoholiniai gèrimai & 9,3 & 11,0 & 9,2 \\
\hline Tabako gaminiai & 2,4 & 3,2 & 3,8 \\
\hline Drabužiai ir avalynè & 23,0 & 24,8 & 20,4 \\
\hline Būstas, vanduo, elektra, dujos, kuras & 8,0 & 8,0 & 7,2 \\
\hline $\begin{array}{l}\text { Būsto apstatymas, namų apyvokos ịranga ir kasdienè būsto } \\
\text { priežiūra }\end{array}$ & 38,2 & 45,6 & 25,2 \\
\hline Sveikatos priežiūra & 10,3 & 11,3 & 14,7 \\
\hline Transportas & 33,0 & 33,6 & 21,3 \\
\hline Ryšiai & 8,7 & 6,8 & 5,1 \\
\hline Poilsis ir kultūra & 53,8 & 49,2 & 35,6 \\
\hline Švietimas & 29,3 & 21,7 & 18,3 \\
\hline Viešbučiai, kavinès, restoranai, valgyklos & 19,6 & 18,5 & 18,4 \\
\hline Ivairios prekès ir paslaugos & 27,2 & 22,7 & 21,1 \\
\hline
\end{tabular}

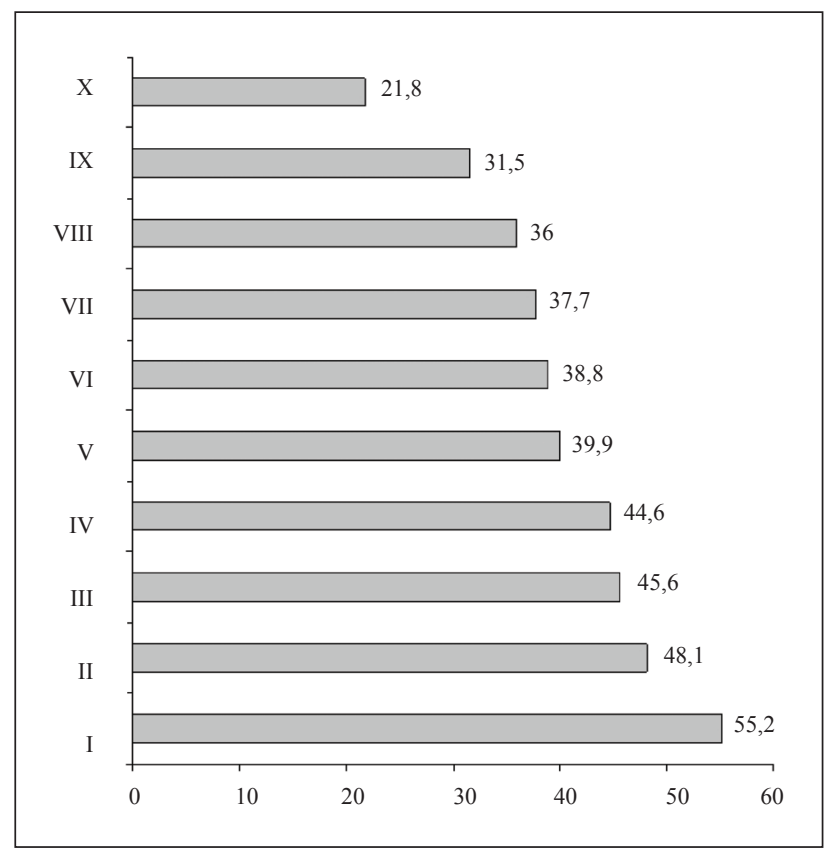

6 pav. Išlaidų maistui lyginamoji dalis vartojimo išlaidose $2008 \mathrm{~m}$. (pagal decilių grupes)

Fig. 6. Proportion of consumption expenditure on food in 2008 (by decile groups)

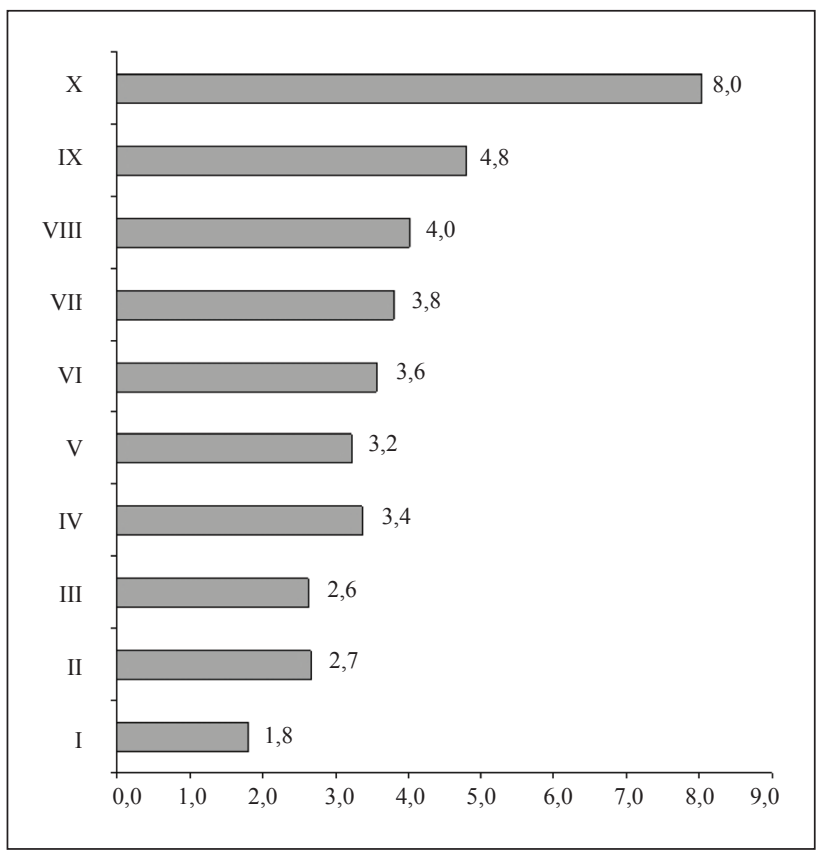

7 pav. Išlaidų poilsiui ir kultūrai lyginamoji dalis vartojimo išlaidose $2008 \mathrm{~m}$. (pagal decilių grupes)

Fig. 7. Proportion of consumption expenditure on recreation and culture (by decile groups) 


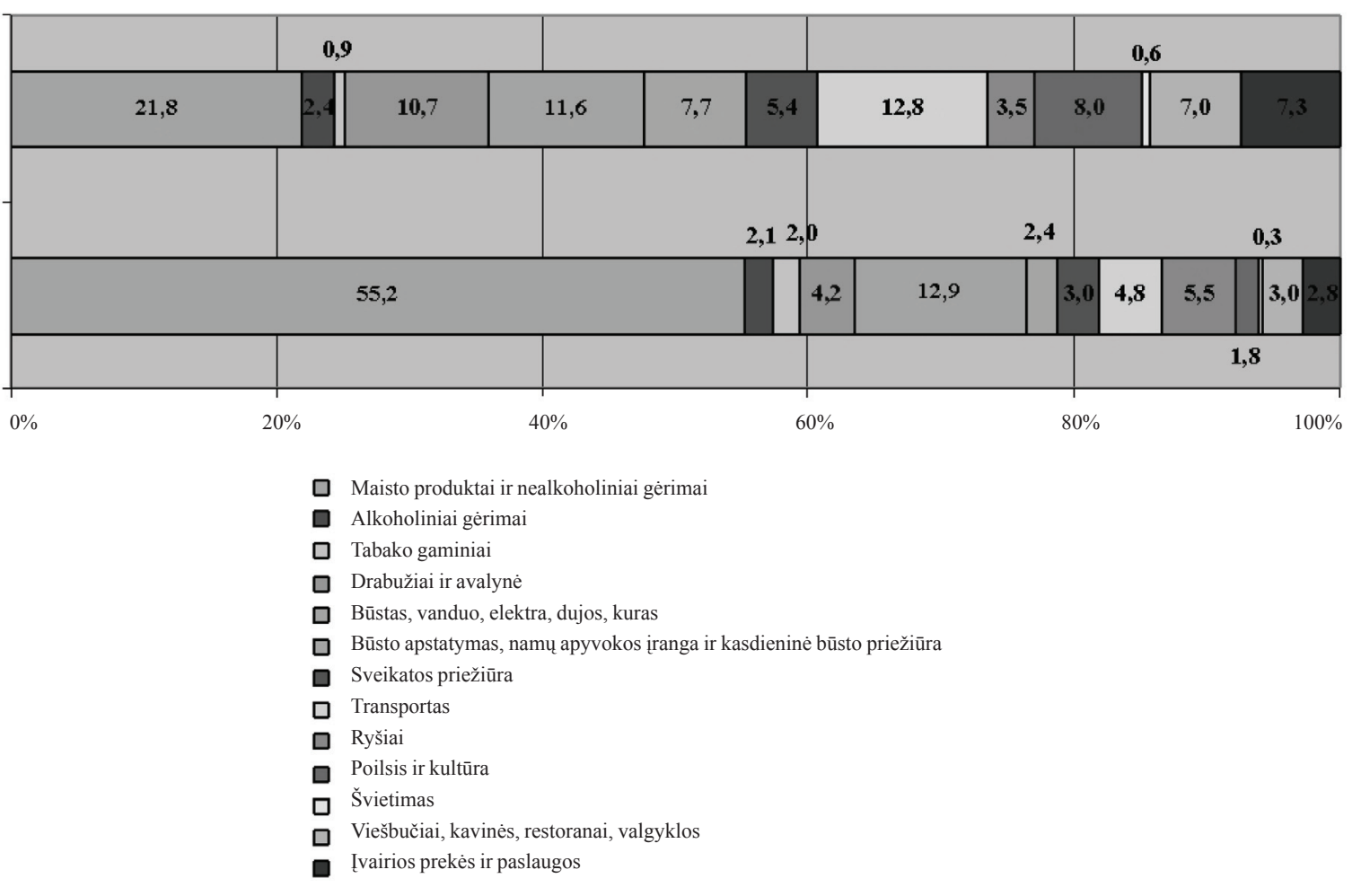

8 pav. Lietuvos gyventojų vartojimo išlaidų pasiskirstymas kraštutiniuose deciliuose 2008 m. (proc.)

Fig. 8. Consumption expenditure distribution in the highest and lowest deciles of Lithuanian population in 2008 (per cent)

Remiantis vartojimo išlaidų pasiskirstymo tendencijomis, tenka konstatuoti, kad gyventojai, patenkantys $\dot{\mathfrak{i}}$ pirmuosius du decilius, visas savo pajamas sunaudoja einamajam vartojimui, būtiniausioms reikmèms (atitinkamai 48,1 ir 55,2 proc. išlaidų skiriama maistui, 6 pav.) ir, deja, dèl ribotų pajamų mažiausiai dèmesio gali skirti poilsiui ir kultūrai, namų apyvokos ịrangai, būsto apstatymui, švietimui, sveikatos priežiūrai, nuo ko labiausiai priklauso žmogaus gyvenimo kokybè. Pažymètini skirtumai ne tik tarp kraštutinių (I ir X) decilių (8 pav.), bet ir tarp IX ir X decilių, kurie transporto, poilsio ir kultūros, būsto reikmių, išlaidų viešbučiams, restoranams, kavinèms grupèse siekia $\mathrm{du}$ ir net tris kartus. Toks atotrūkis tarp gretimų decilių grupių įrodo, kad netgi tame pačiame kvintilyje, kuriam tenka 41 proc. bendrų gyventojų pajamų, pastebima ryški turtinè diferenciacija.

\section{Gyventojų pajamų ir išlaidų santykis}

Lietuvos gyventojų pajamos nuo $2005 \mathrm{~m}$. augo dviženkliais tempais. Tiesa, iki $2008 \mathrm{~m}$. pajamų prieaugis kasmet vis didèdavo ir vidutiniškai siekè 20 proc., o 2009 m. augimas sulètejo iki 14,8 proc. Dèl aukšto infliacijos rodiklio pajamos realiąja išraiška didèjo lèčiausiai nuo pat įstojimo į ES. 2009 m. namų ūkių disponuojamos pajamos beveik trečdaliu ( 28,7 proc.) viršijo vartojimo išlaidas (9 pav.). Vertinant pastarojo laikotarpio namų ūkių disponuojamų pajamų pokyčius, tenka konstatuoti, kad tiek namų ūkių pajamos, tiek gyventojų perkamoji galia sumažès. Vidutinès namų ūkio nario disponuojamos pajamos sumenks labiau nei darbo užmokestis dèl aukštos darbo praradimo tikimybès, nes netekus darbo bent vienam šeimos nariui, namų ūkio pajamos sumažèja. Be to, smunkant atlyginimams, mažinamos ir socialinès išmokos.

Analizuojant disponuojamąsias pajamas ir vartojimą taip pat galima daryti išvadas apie gyventojų polinkius vartoti, t. y. pajamų dalis, kurią namų ūkis vidutiniškai skiria vartojimui, rodo absoliučiai vienpusiškai naudojamas pajamas: labai maža pajamų dalis skiriama taupyti ir investuoti (Misiūnas, Bratčikovienè 2007; Bikas 2008). 2009 m. „Spinter tyrimų“ atliktos gyventojų apklausos duomenimis, mažiau nei pusè visų respondentų atidejo pinigų santaupoms ar pasirengimui juodai dienai, tam skirdami vidutiniškai dešimtadalį uždirbtų lèšų. Daugiau nei pusė (55 proc.) apklausos dalyvių visas uždirbtas pajamas išleido nieko nesutaupydami. Sunkmečio sąlygomis apklaustieji ketina mažiau išleisti pramogoms ir maistui, aprangai ir avalynei, transportui ir komunikacijoms. Mažiausias pajamas gaunantys gyventojai, savaime suprantama, yra priversti taupyti netgi būtiniausių reikmių - maisto ir būsto išlaikymo - sąskaita. 


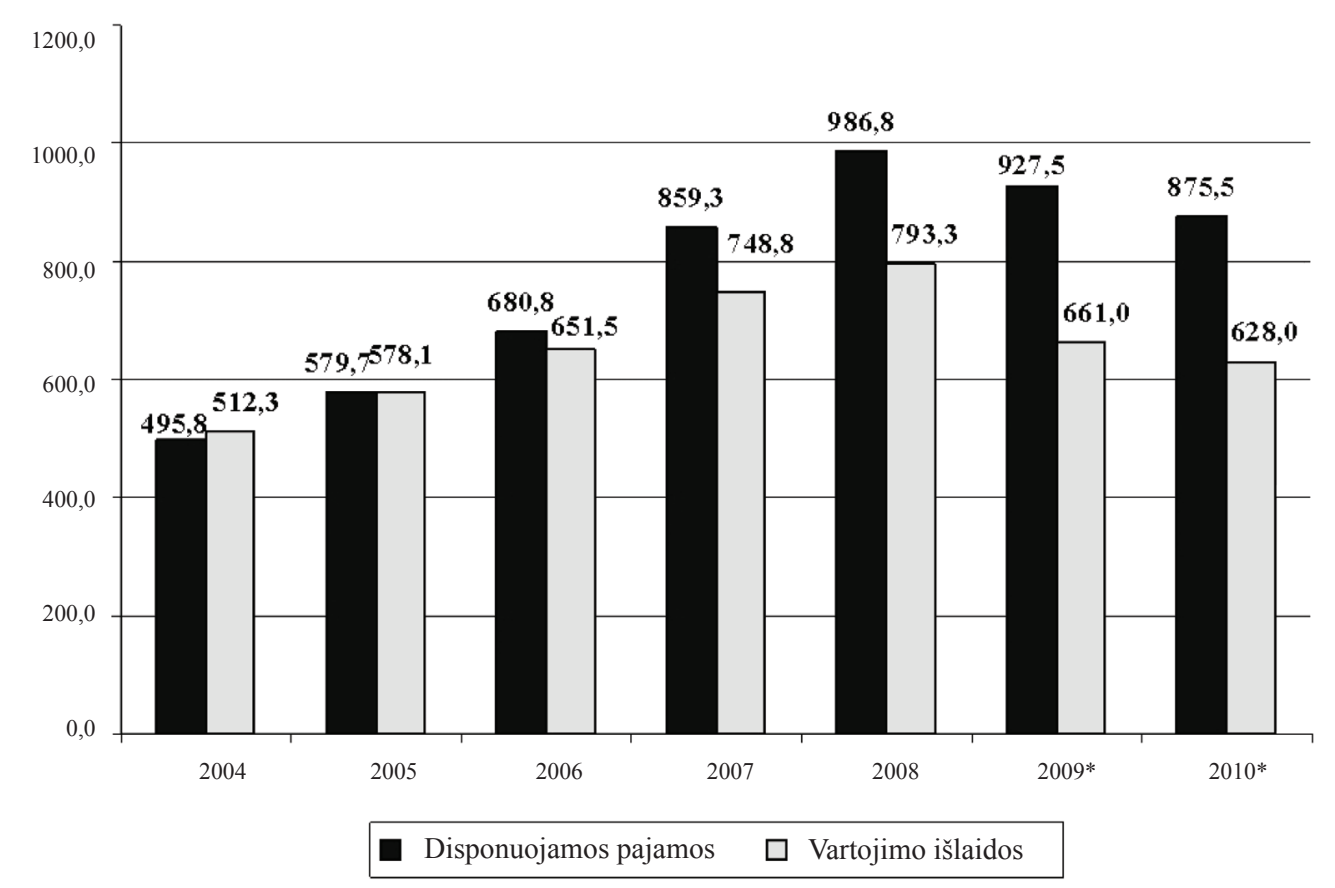

* Autoriaus prognozès.

9 pav. Vidutinès namų ūkio nario pajamos ir išlaidos (remiantis Statistikos departamento duomenimis, Lt)

Fig. 9. Average income and expenditure of household member (according to the data of Statistics Lithuania, LTL)

Vertinant pastarųjų metų valstybės vykdomą ekonominę politiką ir Lietuvos vartotojų elgseną, išryškèja dvi priešingos tendencijos: pirma, stipri orientacija ị vartotoju visuomenès kūrimą, kuri dabar pasaulyje susilaukia vis didesnès kritikos, ir antra, beveik tuo pačiu metu vykstantis priešingas procesas - prievartinis Lietuvos gyventojų vartojimo masto mažinimas, tiek namų ūkių, tiek viešojo sektoriaus vartojimo išlaidų ,„sutraukimas“. Tačiau šio vartotojiškumo apribojimo pagrindine priežastis - ne vartojimo išlaidų struktūros tobulinimas, stengiantis nukreipti išlaidų apimtis ị sveikatos, švietimo, kultūros sritis, o beatodairiškas makrofinansinių rodiklių (infliacijos, biudžeto deficito mažinimo) siekimas, stabdantis gyventojų gyvenimo gerovę ir ekonomikos augimą.

\section{Išvados}

1. Ekonomikos augimo, išreikšto BVP, negalima sutapatinti su tolygiu gyvenimo kokybės gerèjimu. Siekiant pereiti ị naujaji darnios ekonomikos etapą, prekių ir paslaugų kūrimas turètų būti nukreiptas visuomenes gerovei užtikrinti, o ne nuolat didinti pinigu kiekị. Gyvenimo gerove lemia ne tiek makrofinansiniai, kiek socialiniai ir ekologiniai veiksniai. Todèl vertinant gyvenimo kokybę greta ekonominių rodiklių didžiulis vaidmuo tenka ir socialiniams, ekologiniams, darnios ekonominès gerovès indeksams, orientuotiems ị sveikatos, gamtos ir sveikos aplinkos išsau- gojimą, švarią gamybą, atsinaujinančiųjų energijos šaltinių pramonę, ekologinę žemdirbystę.

2. Autoriaus atlikta objektyvių statistinių duomenų (BVP vienam gyventojui ir Džini koeficiento) ir subjektyvaus gyventojų vertinimo (visuomenès pasitenkinimo gyvenimu) analizè atskleidžia, kad ne visada visuomenès gerovè tiesiogiai priklauso nuo šalies ekonominių pajègumų ir ūkio raidos. Pasitenkinimas gyvenimu beveik tolygiai didejja, mažejant turtinei diferenciacijai.

3. Lietuvai vis dar būdingas aukštas pajamų netolygumo lygis. Augant bendrai gyventojų gaunamų pajamų sumai, tuo pačiu metu dideja atotrūkis tarp daugiausiai ir mažiausiai pajamu gaunančį visuomenès grupių. Gilejjanti pajamų diferenciacija visuomenejje kelia gyventojų nepasitenkinimą ir socialinę ittampą, nes, kylant bendram gyvenimo lygiui, atskirų visuomenés grupių padètis negerèja.

4. Autoriaus skaičiavimais, Lietuvos gyventojų vartojimo išlaidų dydžiai kraštutiniuose deciliuose pastaruoju metu skiriasi net 8 kartus. Ypač dideli skirtumai - poilsio ir kultūros, būsto apstatymo, drabužiu ir avalynès ịsigijimo srityse. Gyventojai, patenkantys ị pirmuosius du decilius, didžiąją dalị pajamų sunaudoja einamajam vartojimui ir būtiniausioms reikmèms, mažiausiai dèmesio gali skirti poilsiui ir kultūrai, švietimui, sveikatos priežiūrai - veiksniams, nuo kurių labiausiai priklauso žmogaus gyvenimo kokybẻ. Ryškūs vartojimo išlaidų skirtumai tarp gretimų (IX ir X) decilių, kai kuriose išlaidų grupese siekiantys $d u$ ir net tris kartus, 
liudija ryškią turtinę diferenciaciją ir pasiturinčios visuomenès mažumos egzistavimą, tuo pačiu metu penktadaliui Lietuvos gyventoju balansuojant ties skurdo riba.

5. Didelis atotrūkis tarp gretimų decilių rodo ne tik netolygų šalies gyventojų turtinị pasiskirstymą, bet ir bendrą šalyje vykdomos ekonominés politikos neefektyvumą, netolygu ištekliu pasiskirstymą, galimai nevienodu sąlygu verslui sudaryma ir kitas diskriminacines aplinkybes. Turtinè diferenciacija pamina demokratijos principus, nes disponuojantys didesnèmis pajamomis ar turtu gyventojai turi daug didesnius svertus paveikti politinius, ekonominius procesus tiek mikro-, tiek makrolygiu. Netolygus turto ir pajamų pasiskirstymas dabartineje kartoje lemia nelygias galimybes ir būsimoms kartoms.

6. Lietuvos gyventojų disponuojamųų pajamų ir vartojimo išlaidų analize liudija apie gyventoju polinkius vartoti, labai maža pajamu dalis skiriama taupyti ir investuoti. Tačiau, kita vertus, Lietuvos gyventojų pajamos (ypač sunkmečio sąlygomis) savo dydžiu labai atsilieka nuo ES vidurkio ir nesukuria norimos visuomenès gerovès ir gyvenimo kokybės. Didžioji dalis pajamų vis dar išleidžiama būtiniausioms reikmès užtikrinti, o ne sveikai mitybai, švariai aplinkai, turiningam ir visaverčiam gyvenimui kurti.

\section{Literatūra}

Bauman, Z. 1988. Freedom. Milton Keynes: Open University Press. 106 p.

Bikas, E. 2008. Lithuanian household savings behaviour, Transformations in Business \& Economics 7(3): 154-169.

Celik, S.; Ozerkek, Y. 2009. Panel cointegration analysis of consumer confidence and personal consumption in the European Union, Journal of Business Economics and Management 10(2): 161-168. doi:10.3846/1611-1699.2009.10.161-168-

Gylys, P. 2008a. Ekonomika, antiekonomika ir globalizacija. Vilnius: Vilniaus universiteto leidykla. $443 \mathrm{p}$.

Gylys, P. 2008b. On the scope of the science of economics: a holistic approach, Transformations in Business \& Economics 7(3): 39-52.

Lazutka, R. 2003. Gyventojų pajamų nelygybè, Filosofija. Sociologija 2: 22-29.

Lazutka, R. 2005. Ar BVP augimas garantuoja socialine gerovę? [interaktyvus]. Vilnius: Lietuvos profesinių sąjungų konfederacijos tinklalapis [žiūrèta $2010 \mathrm{~m}$. sausio 4 d.]. Prieiga per internetą: <http://www.lpsk.lt/?lang=lt\&mID=3\&id=198>.

Lazutka, R. 2007. Gerovès kapitalizmo raidos problemos Lietuvoje, iš Lietuvos ekonominés padeties Europoje ir globalioje erdveje analizé: straipsnių rinkinys. Vilnius: Ekonomikos tyrimų centras, 61-82.

Living conditions and welfare. 2006, 2007, 2008, 2009. Europe in Figures - Eurostat Yearbook [interaktyvus]. Luxembourg:
Office for Official Publications of the European Communities [žiūrèta $2010 \mathrm{~m}$. sausio 4 d.]. Prieiga per internetą: $<$ http://epp.eurostat.ec.europa.eu/portal/page/portal/ eurostat/home/>.

Misiūnas, A.; Bratčikovienè, N. 2007. Pajamų nelygybė ir jų normalizavimas, Lietuvos statistikos darbai 46: 112-121.

Norkus, Z. 2007. Ar galim gyventi geriau? Velfarizmas ir jo alternatyvos, Politologija 4(36): 3-39.

Pranulis, V. 2007. Marketingo tyrimai: teorija ir praktika. Vilnius: VU leidykla. $310 \mathrm{p}$.

Rakauskienè, O. G. 2010. Lietuvos gyventojų gyvenimo gerovès raida ir perspektyvos, Regnum est. $1990 \mathrm{~m}$. Kovo 11-osios nepriklausomybes aktui - 20. Liber Amicorum Vytautui Landsbergiui: mokslo straipsnių rinkinys. Vilnius: Mykolo Romerio universiteto leidybos centras, 963-992.

Rakauskienè, O. G.; Makauskaitè, I. 2004. Lietuvos makroekonomikos pasiekimai ir valstybès pajamų didinimo problema, Viešoji politika ir administravimas 7: 33-42.

Second European Quality of Life Survey - First Findings. 2009 [interaktyvus]. Brussels: European Foundation for the Improvement of Living and Working Conditions (Eurofound) [žiūrèta $2010 \mathrm{~m}$. sausio 4 d.]. Prieiga per internetą: <http://www.eurofound.europa.eu/pubdocs/2008/52/en/1/ EF0852EN.pdf>.

Skurdas ir nelygybė ES. 2007. EAPN žinynas [interaktyvus]. Bruxelles, Vilnius: EAPN socialinio ịtraukties darbo grupe [žiūrèta $2010 \mathrm{~m}$. sausio 4 d.]. Prieiga per internetą: <http:// www.skurdas.lt/files/main/skurdas_nelygybeES.pdf > .

Stiglitz, J. E.; Sen, A.; Fitoussi, J.-P. 2009. Report by the Commission on the Measurement of Economic Performance and Social Progress [interaktyvus]. Paris: Commission on the Measurement of Economic Performance and Social Progress [žiūrèta $2010 \mathrm{~m}$. balandžio 5 d.]. Prieiga per internetą: <http://www.scribd.com/doc/19784660/Happiness-andMeasuring-Economic-Progress-by-Joseph-Stiglitz $>$.

Šileika, A.; Blažienė, I. 2000a. Gyventojų pajamų diferenciacija ir skurdas Lietuvoje, Pinigu studijos 3: 32-44.

Šileika, A.; Blažienè, I. 2000b. Lietuvos gyventojų pajamos ir skurdo problema, Ekonomika 51: 136-144.

Šileika, A.; Zabarauskaite, R. 2006. Skurdas, jo matavimas ir tendencijos Lietuvoje, Ekonomika 74: 64-78.

Римашевская, Н. 2007. Сбережение народа [Rimaševskaja, N. Tautos tausojimas]. ИСЭПН РАН. Москва: Наука. 326 c.

Шевяков, А. Ю. 2005. Неравенство и бедность: причины и пути преодоления существующих диспропорций [Cheviakov, A. J. Nelygybė ir skurdas: priežastys ir egzistuojančių disproporcijų įveikimo būdai], Индекс 21: 26.

Шевяков, А. Ю. 2008. Неравенство и формирование новой социальной политики государства [Cheviakov, A. J. Nelygybè ir naujos socialinès politikos valstybeje formavimas], Вестник Российской академии наук 78(4): 304-316.

Vaida LISAUSKAITĖ. Lecturer of Department of Economics, Faculty of Economics and Finance Management, Mykolas Romeris University. Research interests: quality of life of the population, cohesion economics, gender economics, costs of discrimination. 